\title{
Investigational Treatment
}

National Cancer Institute

\section{Source}

National Cancer Institute. Investigational Treatment. NCI Thesaurus. Code C142589.

Any agent or product being assessed in a clinical trial. 